\title{
Hepatorenal Syndrome: Diagnosis and Treatment - newsreel -
}

\author{
AURELIA ENESCU, F. PETRESCU, P. MITRUȚ, ILEANA OCTAVIA PETRESCU, \\ V. PĂDUREANU, ANCA ŞTEFANIA ENESCU
}

University of Medicine and Pharmacy, Craiova, Romania

\begin{abstract}
Hepatorenal syndrome (HRS) is defined as renal failure that occurs in the presence of severe acute or chronic liver disease in the absence of underlying renal pathology. Due to the functional nature of the disease and the absence of specific diagnostic markers, HRS diagnosis is determined based on positive criteria associated with excluding other causes of renal failure in patients with liver cirrhosis and ascites. Differentiation from other types of acute or chronic renal disease is extremely difficult and therapeutic options are limited, prophylactic behavior is most appropriate in patients with severe hepatic disease and risk factors for the installation of hepatorenal syndrome.

Highlighting all precipitating factors of acute renal insufficiency and therapeutic modalities in order to minimize adverse events is an important step in improving the follow-up of the patients with liver cirrhosis. The prognosis is reserved especially for type 1 HRS. Liver transplantation is the best option for patients without contraindications. The therapies introduced in recent years, such as vasoconstrictor drugs or transjugular intrahepatic portosystemic shunt are effective methods in the renal function improvement.
\end{abstract}

Key words: hepatorenal syndrome, liver cirrhosis, renal failure, serum creatinine, vasoconstrictors.

\section{INTRODUCTION}

The concept of HRS was first introduced in 1932 [1] to describe renal failure occurred after biliary tract surgery; in fact, HRS was first described in 1863 [2] as renal dysfunction occurring in patients with advanced liver disease. Hecker, Sherlock, Pepper and Vessin (1950) observed that although renal damage is deadly for patients with liver disease, the pathological examination showed kidneys with normal histology, and later managed to prove that kidneys can be transplanted to a patient without liver damage and remain fully functional. They also demonstrated that renal damage is completely reversible after liver transplantation [3].

In 1996 The International Ascites Club published a consensus on the definition of HRS. HRS is defined as renal failure that occurs in the presence of severe liver disease, acute or chronic, in the absence of underlying renal pathology. HRS is an exclusion diagnosis which requires that hypovolemia, nephrotoxic drugs, sepsis and glomerulonephritis are excluded prior to a diagnosis of HRS. Approximately half of all HRS patients were identified with precipitating factors such as bacterial infection $(57 \%)$, gastrointestinal bleeding $(36 \%)$ or paracentesis $(7 \%)$ [4].

\section{PHYSIOPATHOLOGY}

The main trigger factor for HRS is decreased renal blood flow due to vasoconstriction, renal macrocirculation and microcirculation caused by multiple neurohumoral factors, activation of the renin-angiotensin-aldosterone system, activation of sympathetic nervous system, endothelins and natriuretic peptide. Renal function deterioration in a patient with liver disease appears to be due to unknown nefrotoxines, which are no longer metabolized and eliminated by the liver [5]. Peripheral arterial vasodilatation theory is the most widely accepted mechanism for the explanation of HRS. It says that splanchnic vasodilatation which happens as a result of portal hypertension from cirrhosis is the initiating factor in the development of HRS. Splanchnic vasodilatation is mainly mediated by nitric oxide, but also by other vasodilators such as monoxide, glucagon, vasodilators peptides and others. Splanchnic vasodilatation sequesters blood in the splanchnic vascular bed which leads to reduced arterial blood volume. In the compensated cirrhosis, cardiac contractility increases to counterbalance systemic vascular resistance (which is low).

Through this mechanism effective arterial volume is maintained. In advanced stages cardiac contractility no longer copes because of cirrhotic 
cardiomyopathy development. Because arterial blood volume decreases, compensator neuromuscular vasoconstrictor system like renin-angiotensin-aldosterone system, sympathetic nervous system and arginine vasopressin are stimulated. This causes retention of water and $\mathrm{Na}$ leading to ascites and hyponatraemia, as well as renal and cerebral vasoconstriction even in peripheral vascular bed. The local renal vasodilators such as prostaglandins are initially able to counterbalance the effects of the vasoconstrictor neurohormonal system. The final result of this process is a severe decrease in renal blood flow, which leads to a decrease (severe of renal blood flow) of glomerular filtration rate and development of HRS [6].

\section{DIAGNOSIS CRITERIA}

Due to the lack of a specific biochemical or radiological marker, HRS diagnosis is based on criteria that exclude other causes of kidney damage that frequently occur in cirrhosis. HRS delimitation from other forms of renal failure encountered in severe hepatic disease, particularly in decompensated cirrhosis, is the most difficult problem facing the young clinician. HRS is a form of renal failure in which marked renal vasoconstriction, accompanied by decreased renal blood flow and glomerular filtration rate, does not respond to volemic repletion measures, although there is neither acute tubular necrosis nor any kind of intrinsic renal damage histologically observable [7].

The diagnostic criteria established by The International Ascites Club 1996 are:

Major diagnostic criteria

acute or chronic liver disease with severe hepatic insufficiency and portal hypertension

low rate of glomerular filtrate indicated by serum creatinine $>225 \mathrm{mmol}(>1.5 \mathrm{mg} / \mathrm{dL})$ or creatinine clearance $<40 \mathrm{~mL} / \mathrm{min}$

absence of shock, bacterial infection, a recent treatment with nephrotoxic drugs, the excessive fluid loss (gastrointestinal bleeding, excessive diuresis, weight loss for a few days $>500 \mathrm{~g} /$ day in ascites patients without peripheral edema or $>1 \mathrm{~kg} /$ day in patients with ascites and edema

lack of sustained response after discontinuation of diuretics and administration of 1.51 isotonic saline solution

proteinuria $<0.5 \mathrm{~g} /$ day without ultrasound data of obstructive uropathy or parenchymal renal nephropathy

Additional criteria (minor) which are not

necessary for diagnosis, but usually are present:

- urinary volume $<500 \mathrm{~mL} /$ day

- urinary $\mathrm{Na}<10 \mathrm{mmol} / \mathrm{L}$
- urinary osmolarity $>$ plasma osmolarity

- urinary erythrocytes $<50 /$ field

- Serum Na $<130 \mathrm{mmol} / \mathrm{L}$.

Diagnostic criteria of HRS, developed in 1996, were revised at San Francisco in 2005 [8]:

cirrhosis with ascites

creatinine $>135 \mathrm{mmol} / \mathrm{L}(1.5 \mathrm{mg} / \mathrm{dL})$

no improvement of serum creatinine, after two or more days of treatment with diuretics and albumin (recommended dose of albumin is $1 \mathrm{~g} / \mathrm{kg}$ body weight/day up to a maximum of $100 \mathrm{~g} /$ day)

shock absence

no current or recent treatment with nephrotoxic drugs

the absence of renal parenchymal disease indicated by proteinuria $>500 \mathrm{mg} /$ day, microscopic hematuria (more than 50 red cells per field) and/or abnormal renal ultrasonography

The main differences between the new diagnostic criteria and those developed in 1996 are:

- creatinine clearance was excluded from the diagnostic criteria because it is more complicated and prone to false positive errors, compared to serum creatinine determination.

- renal failure occurring in patients with cirrhosis and bacterial infections, in the absence of septic shock should be considered HRS. 
- it is recommended that the expansion of plasma volume should be achieved through the administration of albumin, preferred to saline solutions because of its superior effect.

\section{CLINICAL AND LABORATORY SIGNS}

HRS has no specific clinical signs. The physical examination mainly reflects the advanced liver disease, kidney damage and presence of circulatory abnormalities. Clinical symptoms include hepatomegaly, ascites, portal hypertension stigmas, pruritus, gynecomastia, coagulopathies, palmar erythema, constitutional disorders such as weakness, fatigue, anorexia, etc.

Circulatory abnormalities include a hyperdynamic circulation and low systemic vascular resistance (low jugular venous pressure, tachy- cardia, skipping pulse). The following laboratory tests are suggestive for the diagnosis of HRS: increased renin activity in plasma, increased norepinephrine activity in plasma, hyponatremia, hyperkalemia, increased serum urea, low blood osmolarity, increased urinary osmolarity, decreased urinary sodium excretion.

Abnormalities of laboratory tests that reflect the severity of liver disease include hyperbilirubinemia, hypoalbuminemia, prolongation of prothrombin time.

\section{Differential diagnosis}

HRS delimitation from other forms of renal failure encountered in severe hepatic damage, particularly in decompensated cirrhosis, is an essential diagnostic problem.

The differential diagnosis of HRS with other forms of renal insufficiency in cirrhosis

\begin{tabular}{|l|c|c|c|}
\hline \multicolumn{1}{|c|}{ Differential diagnostic criteria } & Prerenal failure & Hepatorenal syndrome & Acute tubular necrosis \\
\hline Urinary Na/mEq/L & $<10$ & $<10$ & $>30$ \\
\hline Sodium excretion fraction & $<1$ & $<1$ & $>1$ \\
\hline Urinary/plasmatic osmolarity & $>1$ & $>1$ & $<1$ \\
\hline The response to fluid expansion & Yes & No & No \\
\hline
\end{tabular}

\section{Clinical forms}

The last step in HRS diagnosis is to establish the clinical form of HRS: type 1 HRS or type 2 HRS because the severity, prognosis and survival differs between the two entities:

- Type 1 of HRS - acute form of HRS in which renal failure occurs spontaneously in patients with severe liver disease and is rapidly progressive: creatinine serum reaches $>2.5 \mathrm{mg} / \mathrm{dL}$ and creatinine clearance $<20 \mathrm{~mL} / \mathrm{min}$ in less than two weeks. The prognosis is severe with over $80 \%$ mortality at two weeks through renal or liver failure and bleeding from esophageal varices. Improvement in liver function in acute liver failure, alcoholic hepatitis or within cirrhosis decompensation may lead to spontaneous recovery of renal function [9].

- Type 2 of HRS occurs in patients with ascites resistant to diuretics. Renal failure appears slowly in several months, and the prognosis is similar to type 1 , but after a few months of development (approximately six months).

\section{PRECIPITATING FACTORS}

HRS develops in patients with advanced liver disease, cirrhosis being the most common cause of HRS, but other etiologies include fulminant hepatic failure and severe alcoholic acute hepatitis [10]. HRS may appear spontaneously (usually type 2 ) or may be determined by precipitating factors (in over $70 \%$ of type 1 cases). The most common precipitating factor is spontaneous bacterial peritonitis. Spontaneous bacterial peritonitis represents infection of the ascetic fluid (usually Gram negative enteric bacteria) in the absence of specific intraabdominal sources of sepsis. Spontaneous bacterial peritonitis causes HRS by two mechanisms [11].

- the release of pro-inflammatory cytokines (IL-6 and TNF- $\alpha$ ) and endotoxins, which leads to increased production of nitric oxide and other vasodilators substances.

- sepsis induces cardiomyopathy which leads to less cardiac response.

The second most common precipitating factor for HRS is voluminous paracentesis without plasma expansion. Voluminous paracentesis exacerbates 
hyperdynamic circulation in cirrhosis, which leads to the progressive systemic vasodilation. Gines et al. show that voluminous paracentesis (4-6 L/day) without albumin administration precipitated HRS appearance by $21 \%$ [4, 12]. In contrast, there were no cases of HRS when voluminous paracentesis was performed with administration of albumin intravenously

Gastrointestinal bleeding may induce a systemic anti-inflammatory response associated with proinflammatory cytokines activation which stimulates nitric oxide and other vasodilators. Gastrointestinal bleeding increases susceptibility to infections, a vicious cycle which can generate release of other cytokines and rebleeding. Certain medications such as NSAIDs may precipitate HRS in patients with renal function close to normal.

Biliary obstruction may precipitate HRS due to the action of bile acids and oxidative stress resulting from free tissue destruction. The bile acids may alter the balance of electrolytes and renal water by blocking the protein $\mathrm{Na}$ - hydrogen antiport [13]. The oxidative stress promotes the formation of a variety of vasoconstrictor substances including endothelial 1, F2- isoprostan and cysteinyl leukotriene.

\section{TREATMENT}

\section{Prevention and initial treatment of HRS}

Rapid identification of infection and an adequate antibiotherapy decreased mortality rate in the spontaneous bacterial peritonitis by $50 \%$ to about $18-20 \%$ [14], as well as a reduction in the incidence of HRS (28 versus 41\%) [15]. Antibiotic prophylaxis is recommended in two clinical situations: bleeding from esophageal varices and antecedents of spontaneous bacterial peritonitis. The presence of spontaneous bacterial peritonitis will impose preventive administration of albumin $1-1.5 \mathrm{~g} / \mathrm{kg}$ for three days. Voleme expansion with human albumin to prevent HRS is mandatory in the cases of paracentesis with large volumes $(8 \mathrm{~g} / \mathrm{L}$ ascites evacuated) [16].

The judicious use of diuretics means using the minimum effective dose that prevents diuresis from exceeding the rate of ascites resorption and reaching hypovolemia: the solution is temporarily stopping the diuretic [17]. Choosing the diuretic may be based on urinary Na concentration, the aim being to realize a negative $\mathrm{Na}$ balance : restriction intake to $50 \mathrm{mEq}$ and diuretics so that urinary $\mathrm{Na}$ should be over $80 \mathrm{mEq} / \mathrm{L}$, as well as fluid restriction.
If the initial excretion of $\mathrm{Na}$ is more than $30 \mathrm{mEq} / \mathrm{L}$, spironolactone alone is administered between 10$30 \mathrm{mEq} / \mathrm{L}$ combined with furosemide, and below $10 \mathrm{mEq} / \mathrm{L}$ paracentesis is usually added. Furosemide will be administered only in combination with spironolactone at a rate of $40 \mathrm{mg} / 100 \mathrm{mg}$ spironolactone.

Advanced cirrhosis with ascites refractory to a diuretic therapy was complicated in $20 \%$ of HRS cases, one year mortality being approximately $50 \%$ [18]. The diagnosis of "refractory ascites" indicates possible future complications like HRS; International Ascites Club, thus defining this therapeutic situation [19].

- ascites resistant to diuretics: ascites which cannot be mobilized by sodium restriction and intensive diuretic therapy (spironolactone $400 \mathrm{mg} /$ day plus $160 \mathrm{mg}$ furosemide/day) over a period of one week or which is early restored after treatment.

- ascites untreatable with diuretics: ascites which cannot be treated or whose recurrence cannot be prevented due to the development of diuretic therapy complications which do not allow the use of an effective dosage. Generally the most common cause of resistance to diuretics is increased $\mathrm{Na}$ intake, but given sodium restriction, other factors are considered: worsening liver function, spontaneous bacterial peritonitis, the use of NSAIDs and aminoglycosides [20].

Initial treatment of HRS includes:

1. Optimal volemic replete: volemic loading test with up to 1.51 physiological saline (abandoned) or human albumin (proved useful).

2. Diagnosis and treatment of precipitating factors (hypovolemia secondary gastrointestinal hemorrhage or diuretics, sepsis)

3. Interruption of nephrotoxic drugs (NSAIDs, aminoglycosides).

\section{HRS treatment}

- The vasoconstrictor therapy

This is the first treatment option for type 1 of HRS. Albumin potentiates the vasoconstrictor effect by improving cardiac function and effectively increasing arterial blood. The vasoconstrictor medication combined with the albumin is recommended as a first line treatment for type 1 of HRS [21]. Response to treatment is characterized by a decrease of serum creatinine and an increase of urinary volume [22].

The development of synthetic vasopressin analogues provides an important progress in the 
HRS treatment. Ornipressin and terlipressin are vasoconstrictor agents which have more effect on mesenteric circulation than on renal or vascular system. Ornipressin cannot be used due to severe ischemic side effects. Terlipressin and albumin administration are the most important treatment options in type 1 of HRS [23]. Terlipressin is effective in $40 \%-60 \%$ of patients with type $1 \mathrm{HRS}$; even if the clinical response to terlipressin treatment is slow, the reduction in serum creatinine level is continuous [24, 25]. Other vasoconstrictor agents used in practice in HRS treatment are somatostatin analogues (octreotide), alpha adrenergic agonists, midodrine and norepinephrine. Several studies have proved their effectiveness, some of which found that they are less effective than terlipressin and some others found that their effectiveness is similar to terlipressin [26]. Therapy with terlipressin and albumin, on the one hand, and albumin alone, on the other hand, were compared in a multicentre randomized controlled trial in 46 patients with HRS, showed improved renal function in the former group (43.5\% versus $8.7 \%, p=0.017)$, but no survival advantage in either group at three months (27\% versus $19 \%, p=0.7$ ) [27]. Midodrine is an oral alpha adrenergic agonist and it is administered as an initial dose of $7.5 \mathrm{mg}$ every eight hours (maximum $15 \mathrm{~g}$ to eight hours) and octreotide could be administered as a continuous infusion with a dose of $50 \mathrm{mcg} /$ hour or subcutaneous with a dose of $100-200 \mathrm{mcg} / 8$ hours. In combination with midodrine and octreotide, albumin is given as an intravenous bolus with a starting dose of $1 \mathrm{~g} / \mathrm{kg}$ (maximum $100 \mathrm{~g}$ ) and a maintenance dose of 20-50 g. Midodrine in combination with octreotide and albumin improve systemic and renal hemodynamic status [28]. Norepinephrine is a general vasoconstrictor agent used in the intensive care unit and it is administered as an intravenous continuous infusion with a dose of 0.5-3 mg/hour. Dopamine and dopamine agonists, vasodilatory prostanoids, natriuretic peptides and endothelin antagonists have not been proved to be effective in clinical studies of HRS [29]. In alcoholic hepatitis, oxypentifylline has been reported to reduce the incidence of HRS, but it has not been shown to improve renal function in established HRS [29]. Endothelin and $\mathrm{N}$-acetylcysteine antagonists have not been tested extensively yet [30]. Treatment with losartan, a highly selective antagonist of type I receptors of angiotensin II improved renal function in patients with chirrosis, with or without ascitis, but further studies are necessary to assess the role losartan has in HRS treatment [20].
- Transjugular intrahepatic portosystemic shunt (TIPS).

TIPS consists of the insertion of an intrahepatic stent that connects portal vein with the hepatic vein. This shunt leads portal blood into the systemic circulation thereby reducing portal pressure and increasing systemic venous return. Unfortunately, most patients with HRS are not eligible for this therapy because of contraindications (INR $>2$, serum bilirubin $>5 \mathrm{mg} / \mathrm{dL}$ and cardiopulmonary disease). Overall survival following TIPS was $81 \%$ at three months, $71 \%$ at six months, $48 \%$ at 12 months, and $35 \%$ at 18 months [31].

- Extracorporeal support systems

Renal replacement therapy may be used to treat specific complications of renal disorder such as metabolic acidosis, hyperkalemia, uremic symptoms [32]. (MARS)

- Molecular absorbent recirculating system

MARS is a modified dialysis technique for albumin and water-soluble substances extraction from the blood. This removes the vasodilatory substances, such as nitric oxide, tumor necrosis factor and cytokines, substances that are involved in the HRS pathogenesis [33]. The MARS group showed improved short-term survival compared with the control group ( survival was 37.5\% at seven days and $25 \%$ at 30 days for MARS versus $0 \%$ at seven days for the control group) [31].

- Liver transplantation

It is the best treatment for HRS [34]. 5-year survival rate for HRS in patients with liver transplantation is $60 \%$ compared to $0 \%$ for patients who were not transplanted [35]. Advantages of a liver transplantation from a living donor include the possibility of a planned surgery with shorter ischemic duration and a younger donor [36].

Pretransplant renal function is a major predictor of posttransplant evolution [37]. Between 58-94\% of HRS patients show a recovery of renal function after kidney transplant [38].

The factors associated with a relapse include the time between onset of HRS and transplantation (over 4-6 weeks), dialysis for more than eight weeks, serum creatinine over $2 \mathrm{mg} / \mathrm{dL}$. These patients might benefit from simultaneous liver and kidney transplantation.

\section{PROGNOSIS}

Since HRS is one of the most lethal complications of cirrhosis, prognosis is invariably 
poor. Survival ranges from months in type 2 HRS to weeks to months in type 1 HRS $[39,40]$. MELD (model for end-stage liver disease) is an internationally recognised scoring system developed for patients with advanced liver disease that is a predictor of three-month mortality and determines priority listing for liver transplantation [31, 39]. Type 1 HRS patients had a MELD score $\geq 20$ and an average survival of one month [39]. For type 2 HRS, the average survival was 11 months for a MELD score $<20$ and three months for a MELD score $\geq 20$ [39]. In a 2006 study, Schepke et al. showed that in 88 patients with cirrhosis and renal failure, some with HRS and non-HRS renal impairment, the estimated survival time was 3.4 months for type $1 \mathrm{HRS}, 10.9$ months for type 2 HRS, and 16.1 months for non-HRS renal impairment [40]. Survival was affected adversely by an increase in serum creatinine and bilirubin, while an increase in serum albumin had a beneficial effect [31]. Higher serum creatinine on admission and a urinary sodium $<5 \mathrm{mEq} / \mathrm{L}$ were associated negatively with survival [31].

\section{PROPHYLAXIS}

It is generally considered that prophylactic treatment may be beneficial in reducing the risk of developing HRS, because patients that received albumin plus cefotaxime had a lower incidence of developing renal impairment than patients that received cefotaxime alone $(10 \%$ versus $33 \%, \mathrm{p}<$ $0.01)$ [31].

\section{CONCLUSIONS}

HRS is a syndrome characterized by renal functional failure due to terminal liver damage. In the past decade a great deal has been revealed about the pathophysiology, clinical manifestations and history of HRS. Standard diagnostic criteria have been developed and globally implemented, which allows a uniform diagnosis and consistency of disease reporting. Limitations in diagnostic criteria still exist since we do not have a specific marker for HRS.

Future research aims to include a reliable diagnostic method for HRS. This is important for diagnosis in an early stage and thus treatment would have better effects through increasing survival. Currently, there are several treatment options, but the only one that offers a chance to healing and longevity is liver transplantation.

Conflicts of interest. There are no conflicts of interest.

All authors have equal contributions.

Sindromul hepatorenal (SHR) este definit ca insuficiență renală care apare in prezența unei boli hepatice severe acute sau cronice în absența unei patologii renale preexistente. Datorită caracterului funcțional al afecțiunii și absenței markerilor specifici de diagnostic, diagnosticul SHR se stabileşte pe baza unor criterii pozitive asociate cu excluderea altor cauze de insuficiență renală la pacientul cu ciroză hepatică şi ascită. Diferențierea de alte tipuri de afectare renală acută sau cronică fiind extrem de dificilă şi optiunile terapeutice limitate, conduita profilactică este cea mai potrivită în cazul pacienților cu afectare hepatică severă şi factori de risc pentru instalarea unui sindrom hepatorenal.

Evidențierea tuturor factorilor precipitanți ai instalării insuficienței renale acute şi modalitățile terapeutice prin care le putem evita efectul patologic constituie un demers important în optimizarea dispensarizării bolnavilor cu ciroză hepatică. Prognosticul este rezervat în special în SHR tip 1. Transplantul hepatic este cea mai bună opțiune în cazul pacienților fără contraindicații la procedură. Terapiile introduse în ultimii ani, cum ar fi: drogurile vasoconstrictoare sau şunt transjugular intrahepatic portosistemic, sunt metode eficiente în îmbunătățirea funcției renale.

Correspondence to: Vlad Pădureanu, $\mathrm{MD}, \mathrm{PhD}$

University of Medicine and Pharmacy Craiova, Romania

Address: 2 Petru Rares Str, Craiova, Dolj, 200349, Romania

Mobile: + 40722567874

E-mail: vldpadureanu@gmail.com or vldpadureanu@yahoo.com 


\section{REFERENCES}

1. ANGELI P., MERKEL C. Pathogenesis and management of hepatorenal syndrome in patients with cirrhosis. J Hepatol. 2008; 48(Suppl 1):S93-103.

2. PHAM PT., PHAM PC., RASTOGI A., WILKINSON AH. Review article: current management of renal dysfunction in the cirrhotic patient. Aliment Pharmacol Ther. 2005; 21(8):949-61.

3. CÁRDENAS A., GINÈS P. Hepatorenal syndrome. Clin Liver Dis. 2006; 10(2):371-85.

4. GINÈS A., ESCORSELL A., GINÈS P., SALÓ J., JIMÉNEZ W., INGLADA L., et al. Incidence, predictive factors, and prognosis of the hepatorenal syndrome in cirrhosis with ascites. Gastroenterology. 1993; 105(1):229-36.

5. ARROYO V., TERRA C., GINÈS P. Advances in the pathogenesis and treatment of type-1 and type-2 hepatorenal syndrome. J Hepatol. 2007; 46(5):935-46.

6. TSOCHATZIS EA., BOSCH J., BURROUGHS AK. Liver cirrhosis. Lancet. 2014; 383(9930):1749-61.

7. ARROYO V., GINÈS P., GERBES AL., DUDLEY FJ., GENTILINI P., LAFFI G., et al. Definition and diagnostic criteria of refractory ascites and hepatorenal syndrome in cirrhosis. International Ascites Club. Hepatology. 1996; 23(1):164-76.

8. SALERNO F., GERBES A., GINĖS P., WONG F., ARROYO V. Diagnosis, prevention and treatment of hepatorenal syndrome in cirrhosis. Gut. 2007; 56(9):1310-8.

9. CHOLONGITAS E., CALVARUSO V., SENZOLO M., PATCH D., SHAW S., O'BEIRNE J., et al. RIFLE classification as predictive factor of mortality in patients with cirrhosis admitted to intensive care unit. J Gastroenterol Hepatol. 2009; 24(10):1639-47.

10. MYERS RP., LEE SS. Cirrhotic cardiomyopathy and liver transplantation. Liver Transpl. 2000; 6(4 Suppl 1):S44-52.

11. BERNARDI M., RUBBOLI A., TREVISANI F., CANCELLIERI C., LIGABUE A., BARALDINI M., et al. Reduced cardiovascular responsiveness to exercise-induced sympathoadrenergic stimulation in patients with cirrhosis. J Hepatol. 1991; 12(2):207-16.

12. MONCRIEF K., KAUFMAN S. Splenic baroreceptors control splenic afferent nerve activity. Am J Physiol Regul Integr Comp Physiol. 2006; 290(2):R352-6.

13. GUARNER C., SORIANO G., TOMAS A., BULBENA O., NOVELLA MT., BALANZO J., et al. Increased serum nitrite and nitrate levels in patients with cirrhosis: relationship to endotoxemia. Hepatology. 1993; 18(5):1139-43.

14. ANGELI P. Hepatorenal syndrome. In: Vincent J-L 2006 Yearbook of Intensive Care and Emergency Medicine. Ed. SpringerVerlag, Berlin, 2006; p. 661-70.

15. FERNÁNDEZ J., NAVASA M., PLANAS R., MONTOLIU S., MONFORT D., SORIANO G., et al. Primary prophylaxis of spontaneous bacterial peritonitis delays hepatorenal syndrome and improves survival in cirrhosis. Gastroenterology. 2007; 133(3):818-24.

16. DAGHER L., MOORE K. The hepatorenal syndrome. Gut. 2001;4 9(5):729-37.

17. NIETSCH HH. Management of portal hypertension. J Clin Gastroenterol. 2005; 39(3):232-6.

18. GENZINI T., TORRICELLI FC. Hepatorenal syndrome: an update. Sao Paulo Med J. 2007; 125(1):50-6.

19. SUZUKI H., STANLEY AJ. Current management and novel therapeutic strategies for refractory ascites and hepatorenal syndrome. QJM. 2001; 94(6):293-300.

20. KASHANI A., LANDAVERDE C., MEDICI V., ROSSARO L. Fluid retention in cirrhosis: pathophysiology and management. QJM. 2008; 101(2):71-85.

21. GINÈS P., TORRE A., TERRA C., GUEVARA M. Review article:pharmacological treatment of hepatorenal syndrome. Aliment Pharmacol Ther. 2004; 20(Suppl 3):57-62; discussion 63-4.

22. GINĖS P., CÁRDENAS A., ARROYO V., RODÉS J. Management of cirrhosis and ascites. N Engl J Med. 2004; 350(16):1646-54.

23. MARRERO J., MARTINEZ FJ., HYZY R. Advances in critical care hepatology. Am J Respir Crit Care Med. 2003; 168(12):1421-6.

24. RUNYON BA., AASLD PRACTICE GUIDELINES COMMITTEE. Management of adult patients with ascites due to cirrhosis: an update. Hepatology. 2009; 49(6):2087-107.

25. SOLANKI P., CHAWLA A., GARG R., GUPTA R., JAIN M., SARIN SK. Beneficial effects of terlipressin in hepatorenal syndrome: a prospective, randomized placebo-controlled clinical trial. J Gastroenterol Hepatol. 2003; 18(2):152-6.

26. DUNDAR HZ., YILMAZLAR T. Management of hepatorenal syndrome. World J Nephrol. 2015; 4(2): 277-286.

27. MARTÍN-LLAHÍ M., PÉPIN MN., GUEVARA M., DIAZ F., TORRE A., MONESCILLO A. et al. Terlipressin and albumin vs albumin in patients with cirrhosis and hepatorenal syndrome: a randomized study. Gastroenterology. 2008; 134(5):1352-9.

28. KALAMBOKIS G., ECONOMOU M., FOTOPOULOS A., AL BOKHARHII J., PAPPAS C., KATSARAKI A., et al. The effects of chronic treatment with octreotide versus octreotide plus midodrine on systemic hemodynamics and renal hemodynamics and function in nonazotemic cirrhotic patients with ascites. Am J Gastroenterol. 2005; 100(4):879-85.

29. DAVENPORT A., AHMAD J., AL-KHAFAJI A., KELLUM JA., GENYK YS., NADIM MK. Medical management of hepatorenal syndrome. Nephrol Dial Transplant. 2012; 27(1):34-41.

30. TURBAN S., THULUYATH PJ., ATTA MG. Hepatorenal syndrome. World J Gastroenterol. 2007; 13(30):4046-55.

31. LOW G., ALEXANDER GJ., LOMAS DJ. Hepatorenal syndrome: aetiology, diagnosis, and treatment. Gastroenterol Res Pract. 2015; 2015:207012.

32. VOLK ML., MARRERO JA. Advances in critical care hepatology. Minerva Anestesiol. 2006; 72(5):269-81.

33. KAPTANOGLU L., BLEI AT. Current status of liver support systems. Clin Liver Dis. 2000; 4(3):711-29,

34. BRENSING KA., TEXTOR J., PERZ J., SCHIEDERMAIER P., RAAB P., STRUNK H., et al. Long term outcome after transjugular intrahepatic portosystemic stent-shunt in non-transplant cirrhotics with hepatorenal syndrome: a phase II study. Gut. 2000; 47(2):288-95. 
35. SEN S., MOOKERJEE RP., DAVIES NA., WILLIAMS R., JALAN R. Review article: the molecular adsorbents recirculating system (MARS) in liver failure. Aliment Pharmacol Ther. 2002; 16(Suppl 5):32-8.

36. WIKLUND RA. Preoperative preparation of patients with advanced liver disease. Crit Care Med. 2004; 32(4 Suppl):S106-15.

37. SOLIS-HERRUZO JA., DURAN A., FAVELA V., CASTELLANO G., MADRID JL., MUÑOZ-YAGÜE MT., et al. Effects of lumbar sympathetic block on kidney function in cirrhotic patients with hepatorenal syndrome. J Hepatol. 1987; 5(2):167-73.

38. TANDON P., BAIN VG., TSUYUKI RT., KLARENBACH S. Systematic review: renal and other clinically relevant outcomes in hepatorenal syndrome trials. Aliment Pharmacol Ther. 2007; 25(9):1017-28.

39. ALESSANDRIA C., OZDOGAN O., GUEVARA M., RESTUCCIA T., JIMÉNEZ W., ARROYO V., et al. MELD score and clinical type predict prognosis in hepatorenal syndrome: relevance to liver transplantation. Hepatology. 2005; 41(6):1282-9.

40. SCHEPKE M., APPENRODT B., HELLER J., ZIELINSKI J., SAUERBRUCH T. Prognostic factors for patients with cirrhosis and kidney dysfunction in the era of MELD: results of a prospective study. Liver Int. 2006; 26(7):834-9.

Received February 3, 2016 